Landslides (2015) 12:115-133 DOI 10.1007/s10346-014-0539-0 Received: 10 April 2014 Accepted: 5 November 2014 Published online: 21 November 2014 c) Springer-Verlag Berlin Heidelberg 2014
Sergio A. Sepúlveda · Stella M. Moreiras · Marisol Lara · Alejandro Alfaro

\section{Debris flows in the Andean ranges of central Chile and Argentina triggered by 2013 summer storms: characteristics and consequences}

\begin{abstract}
In January and February 2013, heavy rainfall during local summer storms triggered a large number of landslides in the Andes Main and Frontal ranges of central Chile and Argentina $\left(32^{\circ}-34^{\circ} \mathrm{S}\right)$. Most of the mass movements classify as debris flows, while rockfalls and debris avalanches also occurred. The major debris flows occurred in the Maipo and Aconcagua valleys (Chile) and along the Mendoza River valley (Argentina). The debris flows caused serious disruption to the international highway connecting both countries and local roads and produced a large impact on the population of major cities downstream, mainly due to potable water supply cutoffs. Debris flow deposits have silt and clay particles usually ranging between 10 and $20 \%$ by weight, which favors the movement of viscous flows in short, steep lateral gullies. Most of the flows tended to channelize, and the materials were deposited in alluvial fans and cones in areas with previous records of such events. This indicates that they constitute a significant hazard that may not have been properly considered in road infrastructure and potable water supply strategies for the region. This potential hazard may become more serious due to climate change in the near future.
\end{abstract}

Keywords Central Andes · Debris flow · Changing

climate $\cdot$ Rainfall-induced landslides

\section{Introduction}

Natural hazards, human activities, and socio-economic development in the semi-arid Central Andes are strongly influenced by the precipitation regime and climate phenomena. Intense summer or winter rainfall is the main trigger of debris flows in lower altitude regions of Argentina and Chile, respectively (e.g., Sepúlveda and Padilla 2008; Moreiras and Sepúlveda 2013). Over the long term, the warm phase of the El Niño Southern Oscillation (ENSO) has been linked to major landsliding activity and above-average river flows (Moreiras 2005; Sepúlveda et al. 2006; Araneo and Compagnucci 2008). However, the influence of the Pacific Anticyclone seems to be limited to high mountain areas of the Andes Main and Frontal ranges, while hillslope instability in the eastern Precordillera is induced by humid periods of the Atlantic Anticyclone (Moreiras 2006; Moreiras et al. 2012).

An analysis of synoptic situations for summer and winter precipitation events in the Central Andes has recently been documented (Viale and Nuñez 2011; Viale and Garreaud 2014). However, the extreme precipitation processes leading to debris flows are still poorly understood and need further investigation. This paper presents a case study of debris flows that occurred during the Southern Hemisphere summer in January and February 2013, when local but very intense storms triggered a large number of landslides, mainly debris flows, in the Andes Main and Frontal ranges of central Chile and Argentina $\left(32^{\circ}-34^{\circ} \mathrm{S}\right)$. The major debris flows occurred in the Maipo and Aconcagua valleys (Chile) and along the Mendoza River valley (Argentina), some of them simultaneously in both countries while others were induced by more local storms. The debris flows caused serious disruption to the international road infrastructure and had a high impact on the population, mainly due to potable water supply cutoffs to major cities (Moreiras and Sepúlveda 2013).

Two rainfall events on 21 January and 8 February 2013 caused several debris flows in the central Chile Andean valleys. In both cases, the rainfall was very localized, attributed to convective cells that caused short, locally intense precipitations in discrete subcatchments, common in the summer season (Garreaud and Rutllant 1997). In the few meteorological stations around the area, the measured rainfall was null or negligible, with a maximum of $11 \mathrm{~mm}$ of daily precipitation in the Maipo basin for 21 January (DGA 2013; Table 1). Therefore, there is no information on the precise amount of rain that produced the specific flows in the catchments, although there is enough evidence from witnesses that heavy rain caused the landslides. The January 2013 Maipo basin debris flows in Chile produced a high concentration of muddy sediments in the Maipo River, the main source (around $70 \%$ ) of potable water for the capital city of Santiago (population approximately six million). The sediments reached around three times the maximum concentration allowed by the water treatment plants, which had to shut down. For this reason, the water supply to over one million people was cut off for 1 day (Moreiras and Sepúlveda 2013), and many more were affected by a partial suspension of the water supply. The February 2013 events caused similar problems for several days in cities such as Santiago, Valparaíso, Los Andes, San Antonio, and the resort city of Viña del Mar, as well as several smaller towns due to the high sediment concentrations in the Aconcagua and Maipo Rivers, causing major disruption during the peak of the summer holiday season.

In Argentina, dozens of landslide events were triggered by several convective storms spread over a 29 -day period starting on 12 January, with a peak event of 7 February. The triggering rainstorms were clustered in the last 19 days of January and a major episode in the first quarter of February. More than 600 people, mainly tourists, were trapped and isolated along the international road due to the February events and had to be rescued. As the debris material channelized into the Mendoza River, a turbulent current flowed violently into the Potrerillos Reservoir clogging the floodgates of the reservoir. The water level of the reservoir rose $0.6 \mathrm{~m}$ due to sediment accumulation. Meanwhile, potable water pools at plants were affected by muddy waters and the sediments causing interruption in the water supply of Mendoza City, with a population of more than 800,000 (Moreiras and Sepúlveda 2013). Local roads to mountain villages in both countries were also blocked by the flows and rockfalls. However, precipitation records did not exceed $4 \mathrm{~mm}$ at the existing meteorological stations in the 


\section{Recent Landslides}

Table 1 Daily rainfall data in the Maipo drainage basin, Chile, for the debris flow events of 21 January and 8 February 2013

\begin{tabular}{|c|c|c|c|c|c|}
\hline \multirow[t]{2}{*}{ Station } & \multirow{2}{*}{$\begin{array}{l}\text { Altitude } \\
\text { (m asl) }\end{array}$} & \multicolumn{2}{|c|}{ Daily rainfall $(\mathrm{mm})$} & \multicolumn{2}{|c|}{ Monthly rainfall $(\mathrm{mm})$} \\
\hline & & 21 Jan & 08 Feb & Jan & Feb \\
\hline Río Maipo El Manzano ${ }^{1}$ & 850 & 0.7 & 0 & 0.7 & 0 \\
\hline San José de Maipo retén ${ }^{1}$ & 943 & 5.5 & 0 & 5.5 & 0 \\
\hline Río Maipo San Alfonso $^{1}$ & 1092 & 0 & 0.2 & 0 & 0.4 \\
\hline Maitenes bocatoma $^{1}$ & 1143 & 0 & 7 & 1 & 7.6 \\
\hline Maitenes $^{2}$ & 1160 & 0 & 6.6 & N/A & $\mathrm{N} / \mathrm{A}$ \\
\hline San Gabriel $^{1}$ & 1266 & 0 & 4 & 0 & 5.3 \\
\hline Queltehues $^{2}$ & 1310 & 0 & 7 & N/A & $\mathrm{N} / \mathrm{A}$ \\
\hline Alfalfal $^{2}$ & 1350 & 0 & 6,7 & N/A & $\mathrm{N} / \mathrm{A}$ \\
\hline Embalse El Yeso $^{1}$ & 2475 & 11 & 6.8 & 13 & 9.3 \\
\hline
\end{tabular}

Location in shown in Fig. 2

asl above sea level, N/A not available

${ }^{1}$ : Source: Dirección General de Aguas, Ministry of Public Works, Chilean Government

2 : Source: AES Gener Hydroelectric Company

area, and there are no available records for the catchments were the flows where triggered.

In this paper, we describe the most significant summer 2013 debris flow events that occurred in the Main and Frontal ranges in both countries, covering their key geomorphological and sedimentological features, discussion on the impact of this kind of event in terms of hazard to local communities and the main urban centers located downstream, and comment on the influence of changing climate and the risk of future events.

\section{Geological and geomorphological setting}

The study area comprises the Central Andes $\left(32^{\circ}-34^{\circ} \mathrm{S}\right.$, Figs. 1 and 2), mainly structured during the Andean Orogeny that began 20 Ma ago (Ramos 1996) and characterized by a young relief, abrupt topography and high slopes. At this the latitude, the Central Andes is composed of different morphostructural provinces. The Coastal Cordillera and the western part of the Main Cordillera form the Chilean Andes, while the rest of the Main Cordillera, the Frontal Cordillera, and eastern Precordillera form the Central Andes in Argentinean territory (Fig. 1). The study area includes only the Main and Frontal ranges in both countries. The Main Cordillera (MC) (Thiele 1980; Ramos 1996; Wall et al. 1999; Fock 2005) is characterized by Eocene to Miocene volcanic rocks of the Farellones and Abanico Formations in Chile and the Aconcagua Volcanic Complex in Argentina. These rocks overlie Mesozoic marine and volcanic rocks. The marine sedimentary rocks in Chile correlate with the Mendoza Group in Argentina, formed by black shales, sandstones, limestones, and gypsum horizons. Tertiary intrusive and synorogenic continental rocks known as the Santa Maria Formation crop out in Mt. Aconcagua Park, while several intrusive bodies are found on the Chilean side intruding the volcanic formations. The border area between the two countries represents the current volcanic arc from about the $33^{\circ} \mathrm{S}$ southward, including some active volcanoes such as TupungatoTupungatito, San José, and Maipo. This sector is developed by thin-skinned structures such as in the Aconcagua Fold and Thrust
Belt (AFTB) (Ramos 1996), some of which still present seismic activity (Sepúlveda et al. 2008). The MC highest peak is Mt. Aconcagua (6958 m above sea level (asl)) in Argentina, located beside the Mendoza River basin close to the border with Chile. Most of the border area reaches elevations over $5000 \mathrm{~m}$ asl. The main drainage basins to the west in Chile are the Aconcagua and Maipo Rivers, while the Mendoza and Tunuyán Rivers form the largest basins on the Argentinean side of the border.

The Frontal Cordillera (FC) is composed of units formed during the Gondwanide Orogeny of the late Paleozoic to early Mesozoic. It is composed of Permo-Triassic volcanic rocks, mainly of andesitic to silicic magmatic composition, known as the Choiyoi Group. The Tambillos Formation is distinguished by the presence of volcanites, rhyolitic lavas, and lacustrine deposits, whereas the Horcajo Formation has rhyolitic-dacitic pyroclastic rocks and lavas. The subvolcanic rocks of the group are represented by granite bodies such as the Guido Granite, rhyolitic porphyries, and andesitic dikes. Carboniferous sedimentary rocks crop out in contact with Choiyoi Group. Structurally, the FC behaved as a rigid block during the Andean deformation, as shown by the presence of thick-skinned thrusts (Ramos 1996). This system comprises the Cordon del Plata and Cordon del Tigre ranges with altitudes reaching over $6000 \mathrm{~m}$ asl (e.g., Mt. El Plata at $6200 \mathrm{~m}$ asl).

Rainfall in the Andean ranges of central Chile and Argentina varies with topography due to orographic effects (Falvey and Garreaud 2007; Viale and Nuñez 2011). Arid conditions characterize the eastern foothills of the Andes with an annual precipitation of $200 \mathrm{~mm}$, reaching $500 \mathrm{~mm}$ in the highest peaks. In Chile, annual mean precipitation varies from around $300 \mathrm{~mm}$ in the central valley west of the MC to more than 600 and $750 \mathrm{~mm}$ in the high mountains of the Aconcagua and Maipo basins, respectively (DMC 2001). Similarly, the rainfall seasonality changes with longitude: While intense summer rainstorms predominate in the Argentinean territory linked to the Atlantic Anticyclone, in Chile, precipitations are concentrated during autumn and winter forced by the Pacific Anticyclone (Garreaud and Rutllant 1996; Sepúlveda and 


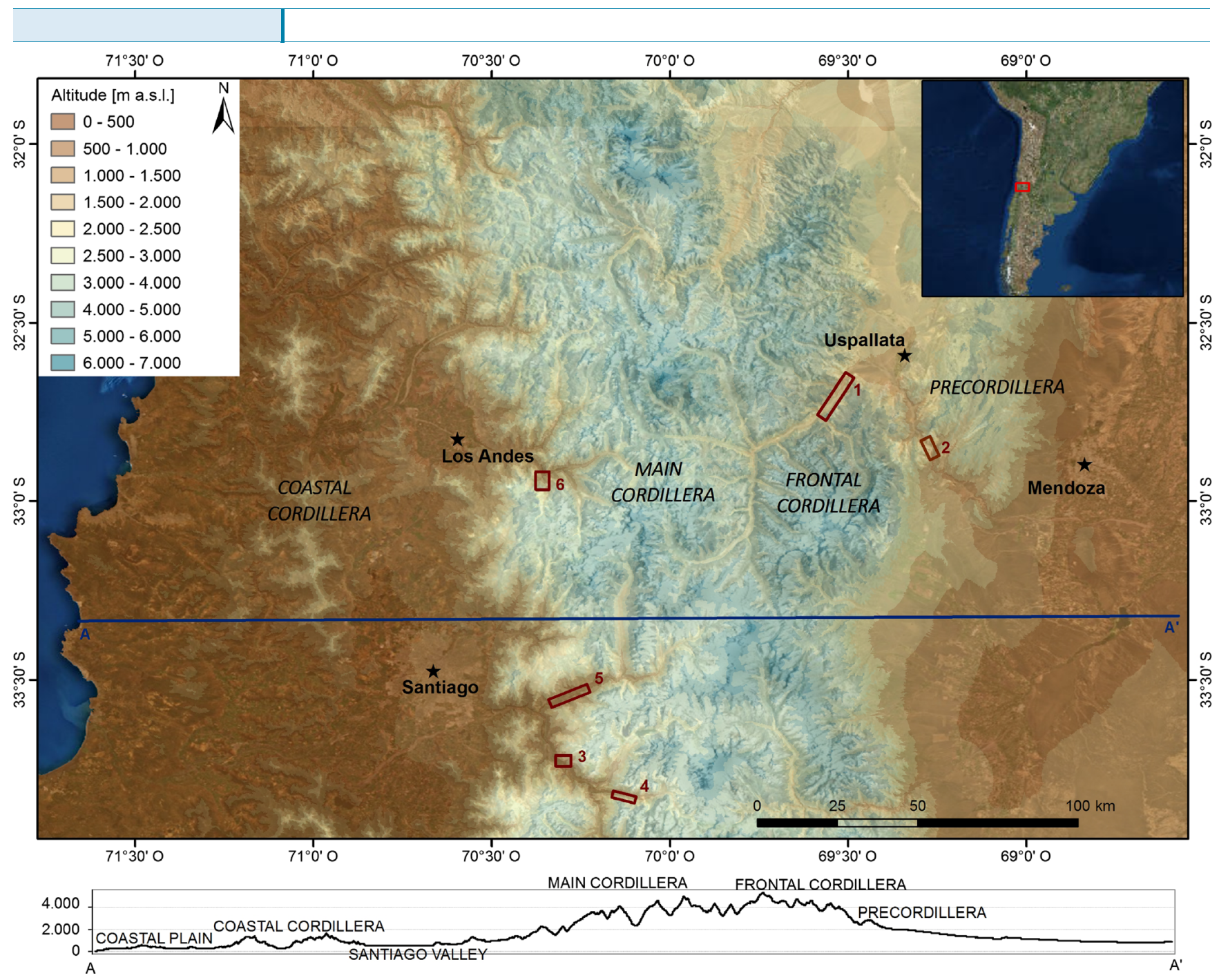

Fig. 1 Shaded relief map with indication of main morphostructural units of central Chile and Argentinean Andes and location of area of landslide events described in this paper

Padilla 2008; Viale and Nuñez 2011) also influencing snow precipitation in the Argentinean Andes. In summer, precipitation events in Chile on altitudes over $2000 \mathrm{~m}$ have mean values from 5 to $10 \mathrm{~mm} / \mathrm{month}$ with a mean of 6 events (Garreaud and Rutllant 1997) while a summer precipitation regime is found on the Argentinan side north of $35^{\circ} \mathrm{S}$ (Viale and Nuñez 2011).

The study area is frequently affected by landslide events, particularly debris flows. In central Chile, several events have been reported over the last decades (Hauser 2000; Sepúlveda and Padilla 2008). Probably the most significant of these took place in May 1993, which affected a large area of the MC including the city of Santiago, where debris flows generated in the mountain front invaded the urban area causing dozens of deaths and largescale destruction (Naranjo and Varela 1996; Sepúlveda et al. 2006). While many reported cases have occurred in autumn and winter periods, there are also some reports of summer debris flows, similar to those described in this paper. For instance, in February 1980 , a number of large flows were triggered by heavy rain in the Aconcagua and Maipo basins, including a fatal case in a tributary of the Mapocho River (Hauser 2000).
More than 300 historical landslide events have been triggered by rainfall along the Mendoza River valley in Argentina since the beginning of the twentieth century (Moreiras 2006). Most of the damaging events have occurred in the localities reported in this paper. Such are the cases of the violent debris flows channelized along Quebrada Seca in 1974 and 2007, both destroying the international route. A debris flow coming from Quebrada del Camino razed a vehicle in 1942 due to an intense storm in this catchment (Moreiras 2005, 2006). In addition, debris flows coming from the so-called Picheuta A zone interrupted the international traffic in 1997 and 2003 (Moreiras 2005).

\section{Methodology}

The debris flow areas were visited through quick field surveys shortly after the events in both Chile and Argentina for identification and preliminary mapping. Later, more detailed field visits were carried out to the main debris flows sites for mapping, deposit characterization, and sampling. Event volumes were estimated where possible based on deposit areas measured on the 


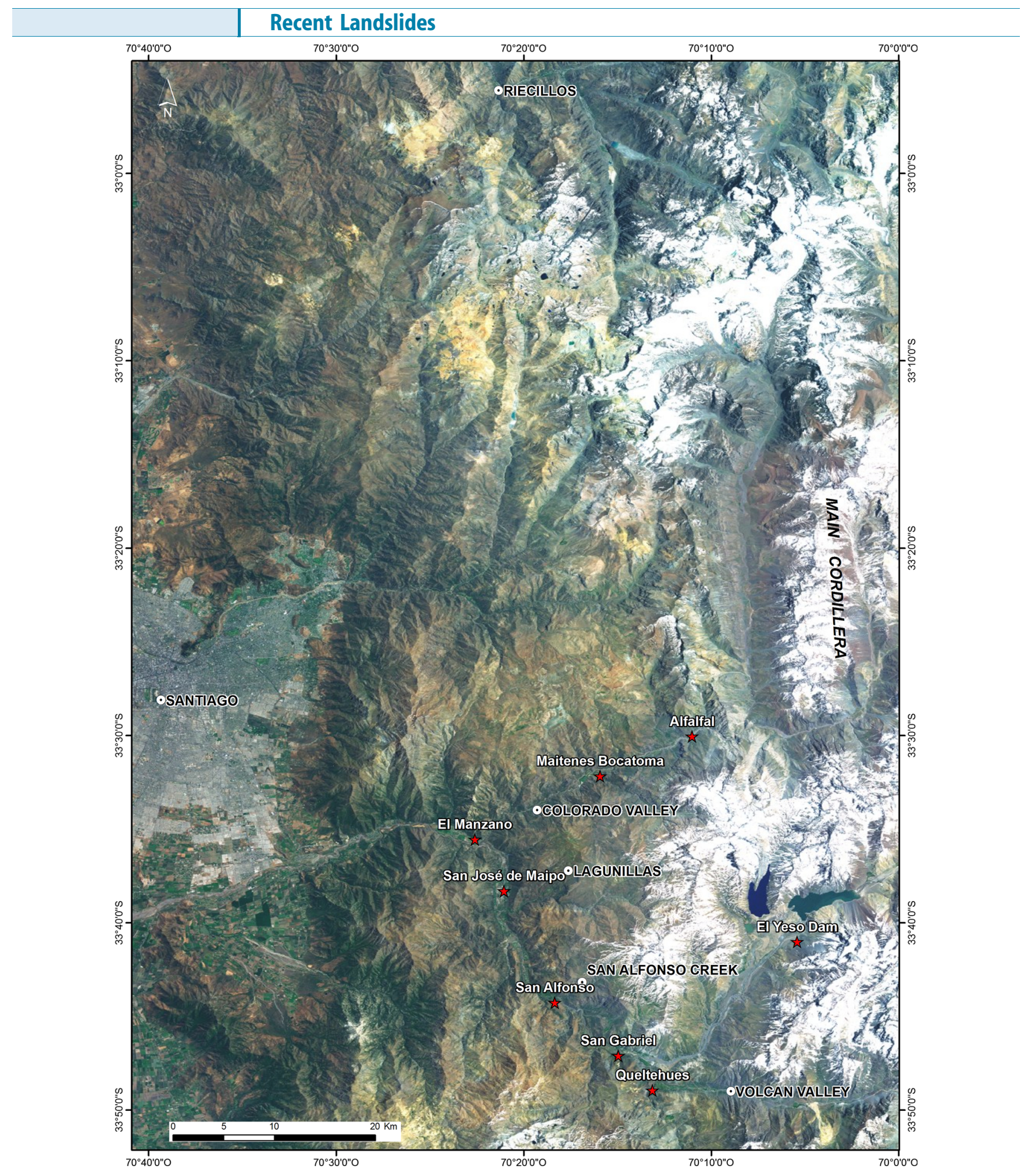

Fig. 2 Google image showing location of main debris flow events that occurred during summer of 2013 in the Maipo and Aconcagua valleys in Chile (dots), and location of meteorological stations indicated in Table 1 (stars)

field and mean thickness of relict deposits. The granulometric distribution of flow deposit matrix was obtained from standard sieving tests at Universidad de Chile and Universidad Nacional de Cuyo laboratories. Coarse-grained material percentages were estimated in the field by visual inspection. Meteorological data was collected from the Chilean Dirección General de Aguas (DGA) and local hydroelectric company AES-GENER. Additional information was recovered from reports of the National Directorate of Roads (DNV) concerning exact time of occurrence, and progressive and removed material removed from the international road. 


\section{The summer 2013 debris flows}

Debris flow and mudflow in the Mendoza River valley, Argentina, in January 2013

The first event occurred on January 12 in Uspallata Village (Fig. 3), located in the valley separating the Frontal Cordillera and Precordillera ranges. The hyperconcentrated flow sourced by intense rainfall affected the Provincial Route 149, which was impacted by a new flow on the following day and again 2 weeks later on January 30. Also, an isolated debris flow was recorded in the Arroyo Negro Creek located $20 \mathrm{~km}$ to the west on January 13 damaging the international road to Chile (Fig. 3). Huge blocks came down into the road.
On January 14, several small debris flows affected the sector known as Guido (FC) (Fig. 4), mobilizing at least a volume of $500 \mathrm{~m}^{3}$ according to the dimensions of the deposits preserved in the area. The events were mainly triggered by water saturation of fine material provided from weathered Permo-Triassic granite belonging to the Choiyoi Group. The susceptibility of this material to generate debris flows had been previously discussed by Moreiras (2005). However, two types of debris flows could be distinguished: (a) debris flows associated with little basins-but steep slopes-draining onto active alluvial fans where flows are channelized, and (b) flows sourced from saturated fine material accumulated on talus cones that mobilized without confinement in pre-existent, well-established channels and may thus be

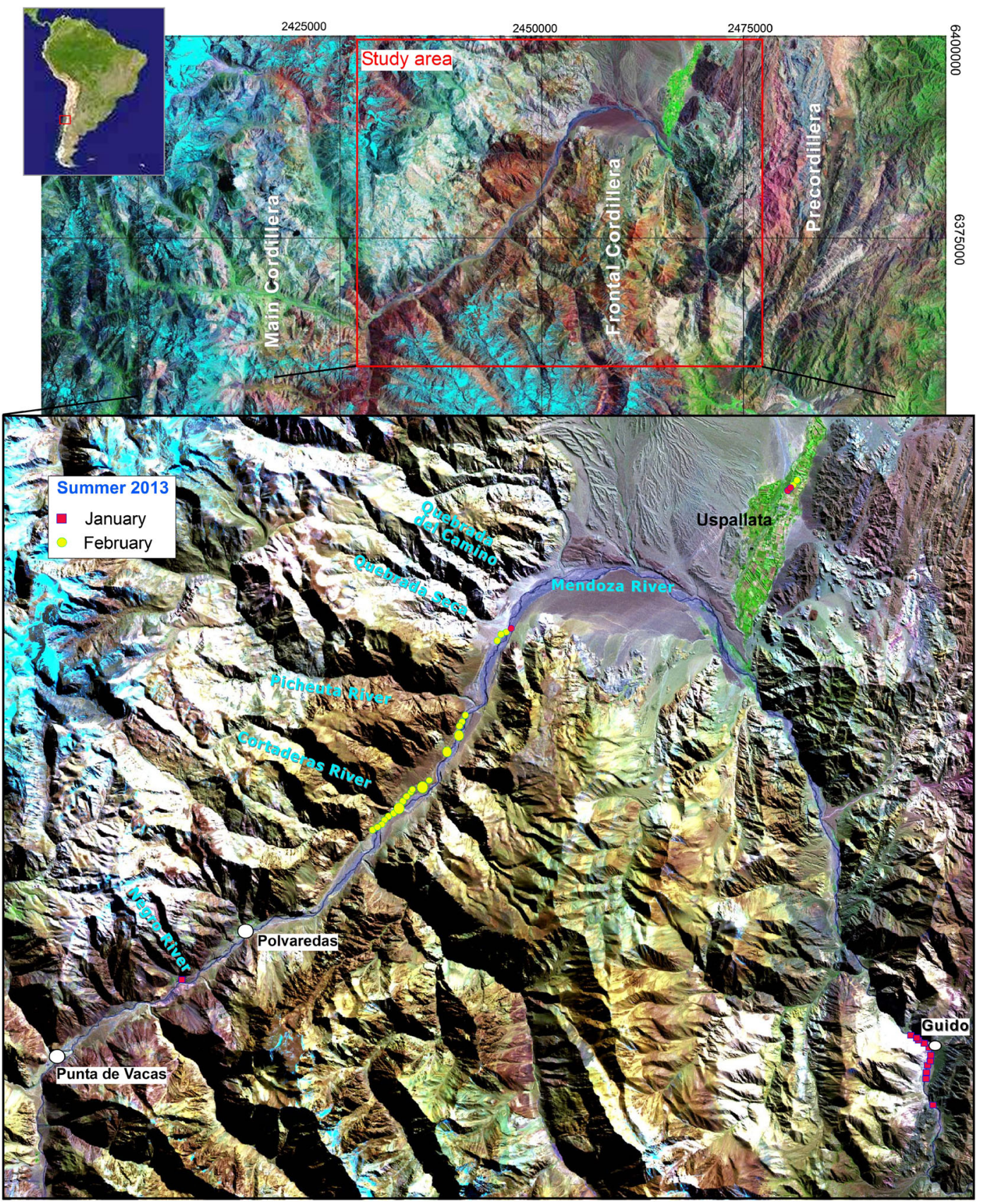

Fig. 3 Google image showing location of events that occurred during summer of 2013 along the international road to Chile in the Mendoza River valley 


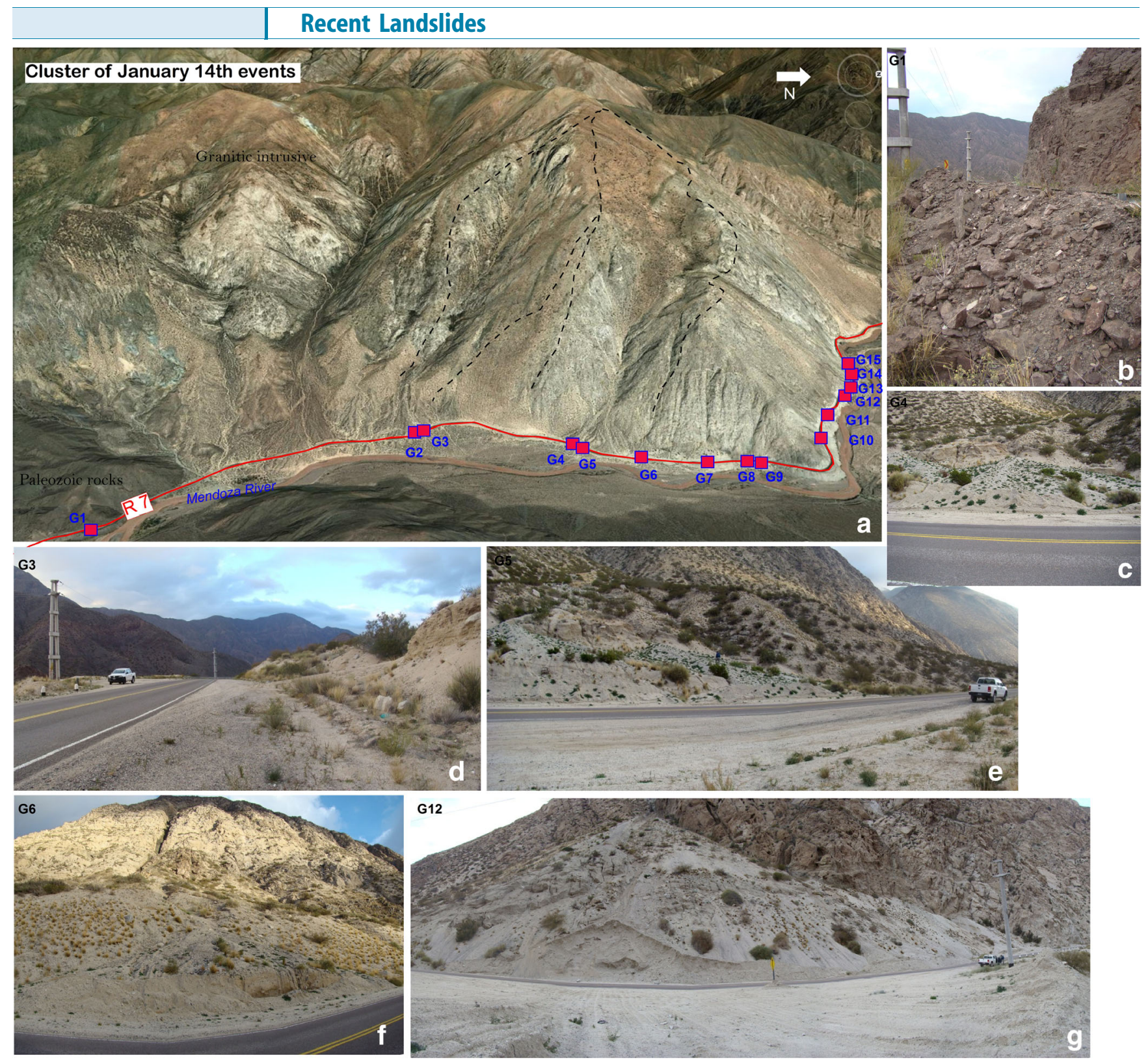

Fig. 4 a Location of debris flows reported at Guido locality (FC) on January 14 along the international road generated from the Permo-Triassic Guido Granite, and a minor rockfall originating from fractured Paleozoic outcrops (G1); $\mathbf{b}$ the $\mathrm{G} 1$ rockfall deposit; $\mathbf{c}$ the $\mathrm{G} 4$ debris flow associated with a minor alluvial cone; $\mathbf{d}$ the $\mathrm{G} 3 \mathrm{debris}$ flow was deposited on the road as a consequence of the lack of any channelization system (culvert); e active alluvial cone of the G3 (please note person for scale); $\mathrm{f}$ the $\mathrm{G} 6$ debris flow associated with talus cone; $\mathrm{g}$ the G12 debris flow generated by mobilization of fine granitic gravel accumulated on a talus cone on Guido Granite

classified as debris avalanches (Hungr et al. 2014). In this area, most of the material was removed by the latter type during January 2013 (Table 2), contrary to what is usually found in this mountain region, where alluvial debris flows are the most common processes generated during summer rainstorms (Moreiras 2006).

Debris avalanches G2 and G3 (Fig. 4) came from a basin with a small area $\left(1.3 \mathrm{~km}^{2}\right)$ and a mean slope of $36^{\circ}$. These events affected the international road. Flows $\mathrm{G}_{4}$ and $\mathrm{G}_{5}$ corresponded to debris flows draining onto an alluvial cone. In contrast, G6, G7, and G8 were generated from a talus cone $2.5 \mathrm{~km}$ long fed by a steep granite outcrop of $76^{\circ}$ slope and may also be classified as debris avalanches following Hungr et al. (2014). The greatest event at the
Guido locality corresponds to G12, a debris avalanche associated with a talus cone that mobilized an estimated volume of $250 \mathrm{~m}^{3}$ of gravel (Fig. 4b).

During the same day, a minor rockfall (G1) was generated from fractured Paleozoic outcrops at the Guido locality. Smaller clasts of $0.1 \mathrm{~m}$ in diameter predominated in this collapse due to damage of the outcrop caused by blasting during road construction, but rock blocks of 0.7-m maximum diameter were also observed (Fig. 4b). The road pavement was not severely damaged, reason for which we presume that collapsed material should be extremely saturated with water, acquiring a flow-like mechanism.

Further minor events were reported during the whole day of January 15 in the Guido locality, mainly in the sector of G9 (Fig. 4), 
Table 2 Major landslide events during 2013 summer in central Chile and Argentina

\begin{tabular}{|c|c|c|c|c|c|}
\hline Location & Event code(s) & Date & Runout (m) & Travel Angle $(H / V)$ & Classification $^{\mathrm{a}}$ \\
\hline Guido (AR, FC) & G1 & $14 / 01 / 2013$ & 95 & 3.28 & Rockfall \\
\hline Guido (AR, FC) & $\mathrm{G} 2, \mathrm{G} 3$ & $14 / 01 / 2013$ & 2667 & 2.6 & Debris flow \\
\hline Guido (AR, FC) & G4, G5 & $14 / 01 / 2013$ & 959 & 2.63 & Debris flow \\
\hline Guido (AR, FC) & G6 & $14 / 01 / 2013$ & 374 & 0.89 & Debris avalanches \\
\hline Guido (AR, FC) & G7 & $14 / 01 / 2013$ & 370 & 2.45 & Debris avalanches \\
\hline Guido (AR, FC) & G8 & $14 / 01 / 2013$ & 237 & 2.15 & Debris avalanches \\
\hline Guido (AR, FC) & G9 & $14 / 01 / 2013$ & 273 & 2.46 & Debris avalanche \\
\hline Guido (AR, FC) & G10 & $14 / 01 / 2013$ & 224 & 3.74 & Debris avalanche \\
\hline Guido (AR, FC) & G11 & $14 / 01 / 2013$ & 374 & 2.32 & Debris avalanche \\
\hline Guido (AR, FC) & G12 & $14 / 01 / 2013$ & 608 & 1.8 & Debris avalanche \\
\hline Guido (AR, FC) & G13 & $14 / 01 / 2013$ & 224 & 3.09 & Debris avalanche \\
\hline Guido (AR, FC) & G14 & $14 / 01 / 2013$ & 223 & 2.57 & Debris avalanche \\
\hline Guido (AR, FC) & G15 & $14 / 01 / 2013$ & 337 & 2.13 & Debris avalanche \\
\hline San Alfonso (CH, MC) & SA & $21 / 01 / 2013$ & $>1300$ & $0.02-0.16$ & Debris flow \\
\hline Volcan River (CH MC) & V1; V2, V3 & $21 / 01 / 2013$ & $>990$ & $0.23-0.45$ & Debris flows \\
\hline Volcan River (CH, MC) & VS & $21 / 01 / 2013$ & 1080 & 0.58 & Debris flow \\
\hline Quebrada Seca (AR, MC) & QS1) & $23 / 01 / 2013$ & 2446 & $>14.1$ & Debris flow \\
\hline Picheuta (AR, MC) & $\mathrm{PC1}, \mathrm{PC2}$ & $07 / 02 / 2013$ & $2229-6722$ & $3.71-6.16$ & Debris flows \\
\hline Picheuta (AR, MC) & PA1 & $07 / 02 / 2013$ & $971-2222$ & $2.25-4.03$ & Debris flow \\
\hline Picheuta (AR, MC) & PA2 & $07 / 02 / 2013$ & $1054-2432$ & $2.7-5.98$ & Debris flow \\
\hline Picheuta (AR, MC) & PB1, PB2 & $07 / 02 / 2013$ & $1036-3420$ & $2.59-3.68$ & Debris flows \\
\hline Quebrada Seca (AR, MC) & QS2,QS3,QS4 & $07 / 02 / 2013$ & 9043 & 9.13 & Debris flows \\
\hline Quebrada del Camino (AR, MC) & QC1 & $07 / 02 / 2013$ & $1682-6246$ & $6.79-8.31$ & Debris flow \\
\hline Cortaderas (AR, MC) & C01, others & $07 / 02 / 2013$ & $437-731$ & $2.53-3.24$ & Debris flows \\
\hline Cortaderas (AR, MC) & - & $07 / 02 / 2013$ & - & - & Rockfalls \\
\hline Colorado River (CH, MC) & $\mathrm{C} 1, \mathrm{C} 2, \mathrm{C} 3, \mathrm{C} 4, \mathrm{C} 5, \mathrm{C} 6$ & $08 / 02 / 2013$ & $600-3000$ & $0.29-0.45$ & Debris flows \\
\hline Colorado River (CH, MC) & $\mathrm{CS} 1, \mathrm{CS} 2, \mathrm{CS} 3$ & $08 / 02 / 2013$ & $1500-5500$ & $0.35-0.49$ & Debris flows \\
\hline Lagunillas (CH, MC) & - & $08 / 02 / 2013$ & $60-700$ & $0.27-0.47$ & Mudflows \\
\hline Riecillos (CH, MC) & R1 & $08 / 02 / 2013$ & $\mathrm{~N} / \mathrm{A}$ & $\mathrm{N} / \mathrm{A}$ & Debris flow \\
\hline Quebrada Seca (AR, MC) & QS5 & $13 / 02 / 2013$ & $\mathrm{~N} / \mathrm{A}$ & $\mathrm{N} / \mathrm{A}$ & \\
\hline
\end{tabular}

AR Argentina, $C H$ Chile, FC Frontal Cordillera, MC Main Cordillera, N/A not available

${ }^{\text {a }}$ After Hungr et al. (2014)

and a violent flow channelized into the Quebrada Seca gully (Fig. 3) interrupting the international traffic of Road 7 to Chile later on January 23. According to a report by the National Directorate of Roads (DNV 2013), a huge amount of debris must have been remobilized from the road due to this event.

\section{The 21 January debris flows in Santiago Cordillera, Chile}

The 21 January event produced important debris flows in the Maipo River drainage basin $\left(33.5^{\circ}-33.8^{\circ} \mathrm{S}\right)$, while minor flows and flooding were reported in the Cachapoal Valley $\left(34^{\circ} \mathrm{S}\right)$, causing road interruptions (Moreiras and Sepúlveda 2013; Sernageomin 2013a, b). The most damaging event occurred in the
San Alfonso Creek and other minor lateral tributaries of the Volcán River in the Maipo basin (Fig. 2 and Table 2).

The debris flow event on this day in San Alfonso Creek, Maipo Valley (Figs. 1, 2, and 5), with an estimated deposit volume of over $5000 \mathrm{~m}^{3}$, followed a narrow, 9.3-km-long gully with a drop in height from about 3200 to $1090 \mathrm{~m}$ asl in its confluence with the Maipo River. The thalweg slope varies between $8^{\circ}$ and $31^{\circ}$. Splash marks at bridges next to the confluence with the Maipo River show that the flow reached heights of up to about $3 \mathrm{~m}$ with marks up to $5 \mathrm{~m}$ upstream. The thickness of the deposits varies between less than $1 \mathrm{~m}$ in the distal zone up to $2 \mathrm{~m}$ in the middle section. The deposits are generally well graded and are composed of 


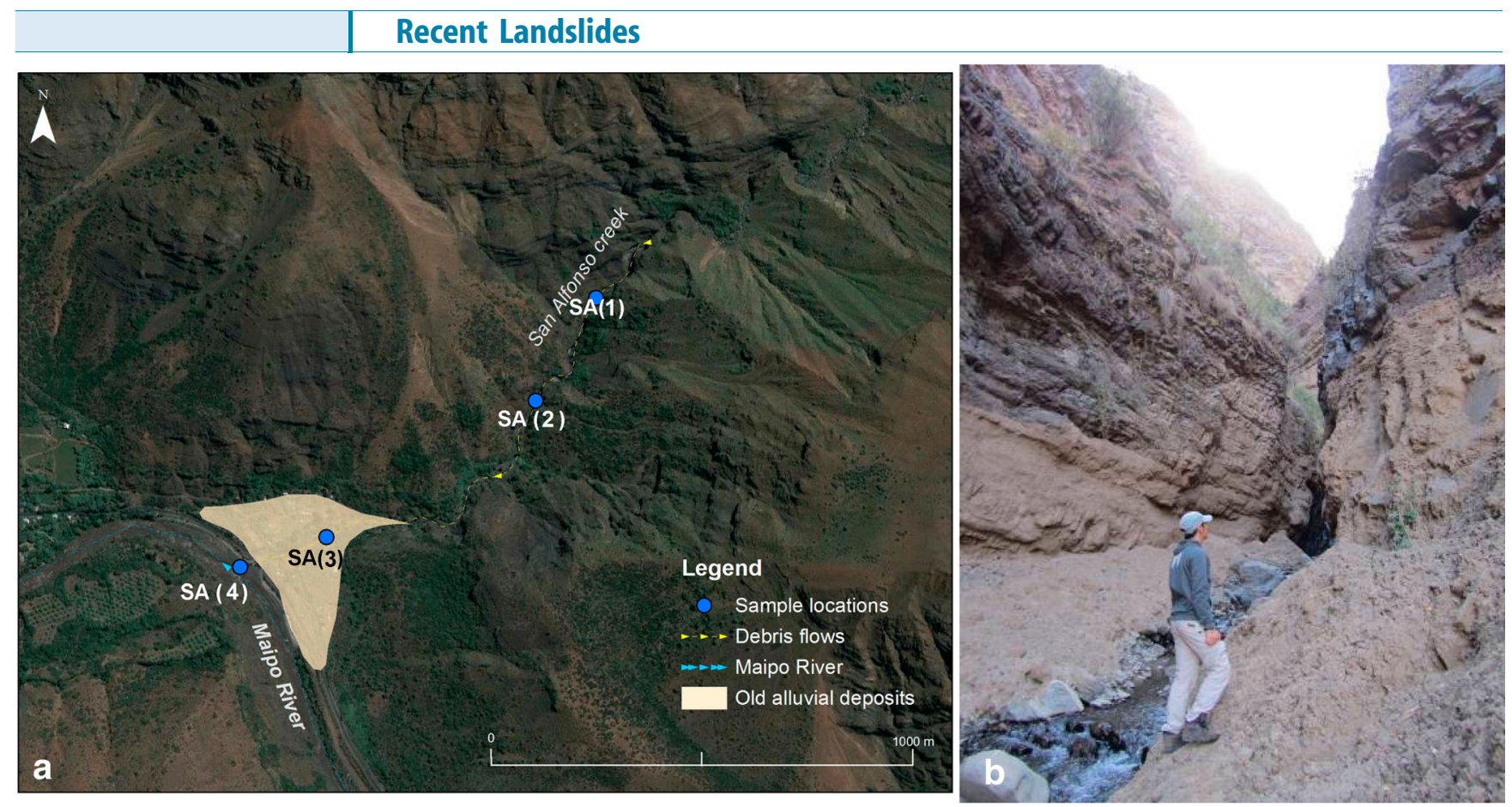

Fig. 5 a Middle and lower sections of San Alfonso Creek with indication of sampling points. b Splash marks and flow deposits at sampling point SA(1)

subangular volcanic clasts, mainly between 5 and $20 \mathrm{~cm}$, but up to about $1-\mathrm{m}$ diameter in a sandy matrix with $10-20 \%$ medium plasticity fines (Fig. 6). The most abundant fine materials are found in the gully middle section.

Meanwhile, the same climatic event caused smaller debris flows and mudflows in at least four lateral, steep creeks in a 4-km-long section plus a fifth a few kilometers further east in the Volcán River valley, a main tributary of the Maipo River (Figs. 2 and 7 and Table 2). The flows deposited on alluvial fans, where older deposits of similar characteristics can be recognized, and affected the G-25 road. The flows originated at heights between 3200 and $3500 \mathrm{~m}$ asl, by remobilization of loose material in the gully channels and adjacent talus cones. The gullies vary between 3.5 and $5.5 \mathrm{~km}$ in length, with average thalweg slopes of $18^{\circ}-27^{\circ}$. The alluvial fans have gradients between $6^{\circ}$ and $15^{\circ}$. The flows tended to incise the former channels up to about $5 \mathrm{~m}$, leaving levees on the edges and forming new erosion and deposition channels in the alluvial fans (Fig. 7). Deposit thicknesses, varied between 1 and $2 \mathrm{~m}$, are poorly graded and are composed mainly of gravel and decimetric blocks of variable proportion in a sandy-silty matrix, sometimes with more abundant clay. In
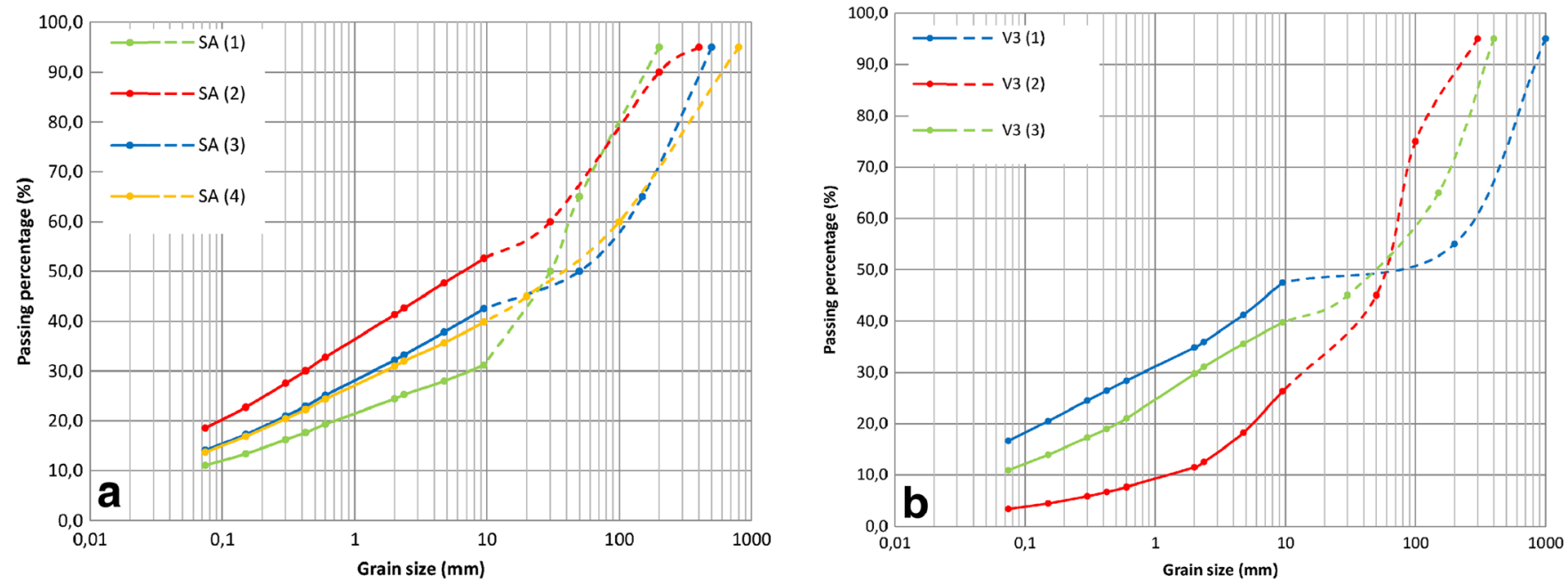

Fig. 6 Granulometric distribution of 21 January 2013 debris flow deposits at a San Alfonso Creek debris flow deposits along the middle and distal sections of the gully and b along a lateral gully (V3) of the Volcán River valley. Dashed lines indicate field estimates, and full lines laboratory analyses of the matrix materials. Sample locations in Figs. 4 and 6 

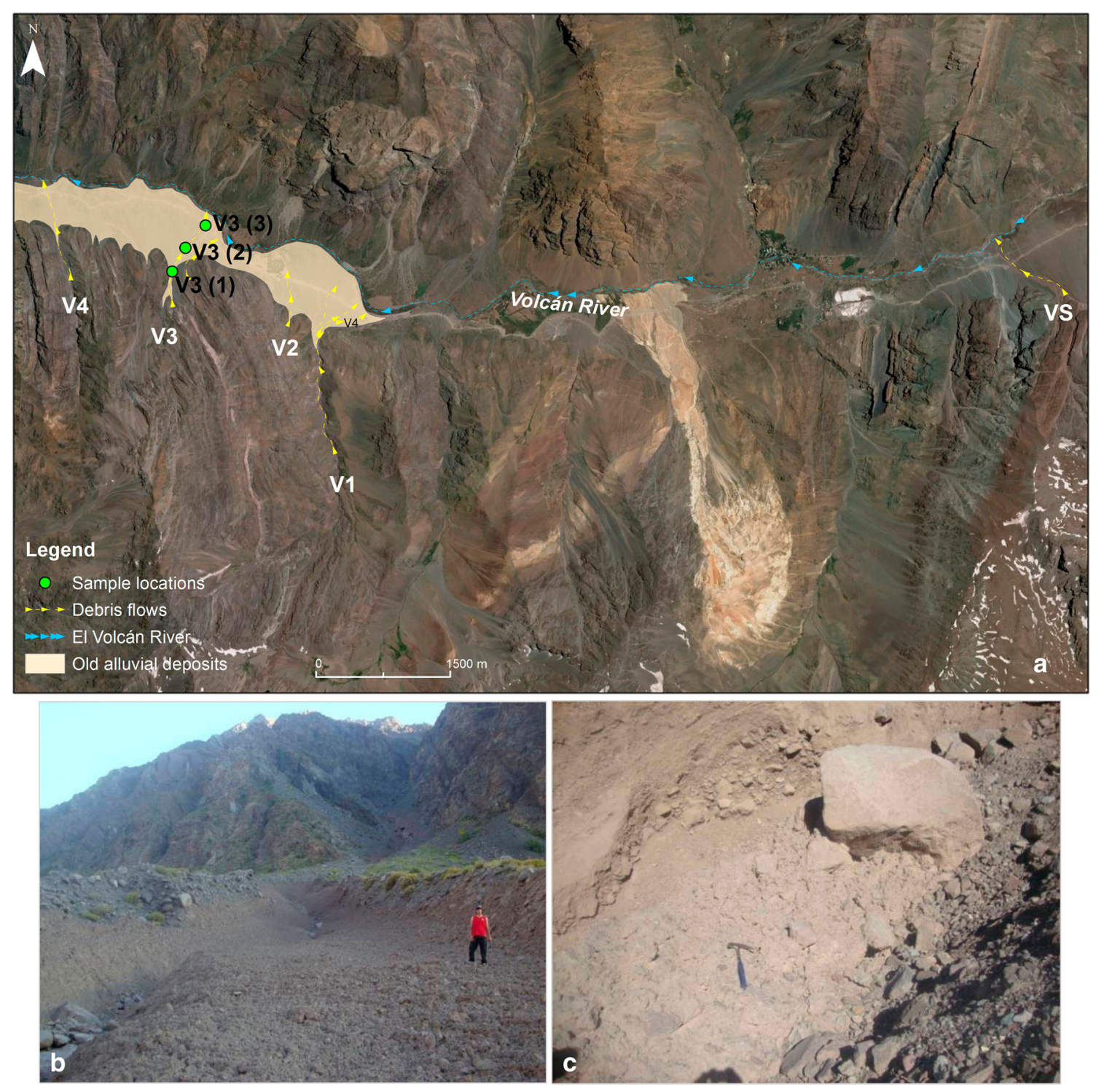

Fig. 7 a Location of debris flows in lateral gullies of the Volcán River; b erosion channel formed by 21 January flow in a lateral creek of the Volcán River; c example of debris flow gravelly deposits

this case, finer materials are found in the upper gully and the distal parts of the alluvial fan (Figs. 6 and 7 ).

\section{The 7-8 February debris flows in central Argentina and Chile}

On 7 February, at least 38 landslide events occurred along a 20-km section of the Mendoza River valley between Polvaredas and Uspallata (Fig. 3). They mainly correspond to debris flows and rockfalls according to Hungr et al. (2014; Table 2). As a consequence, the international traffic was interrupted for 5 days. As a result, 180 trucks were stranded, 660 people were isolated, and 74 tourists had to be evacuated by helicopters.

The first event recorded on February 7 was reported at 4 a.m. near Picheuta ( $\mathrm{PC} 1$, Table 2) associated with an active alluvial cone system identified in this paper as Picheuta C. This channelized debris flow ran nearly $4 \mathrm{~km}$ from the source area descending $960 \mathrm{~m}$ over contrasting slope gradients that range from $55^{\circ}$ in the highest mountainous areas to less than $20^{\circ}$ in the alluvial cone surface. This debris flow with an estimated volume of $115,000 \mathrm{~m}^{3}$ was the largest recorded in these clustered events causing severe damages to the international road (Route $\mathrm{N}^{\circ} 7$, hereafter $\mathrm{R}_{7}$ ). It generated a hole $8 \mathrm{~m}$ deep due to basal block erosion. The thickness of the deposit on the road was measured at $2 \mathrm{~m}$ over $300 \mathrm{~m}$; preserved levees of $5.3 \mathrm{~m}$ were observed (Fig. 8). The mean boulder size was 0.30 to $0.60 \mathrm{~m}$ in diameter, while the largest blocks were $1.3 \mathrm{~m}$ in diameter. The matrix content was low in this deposit, around $20 \%$, where gravel and sand grain sizes predominated. Boulder composition was mainly monolithic, comprising red rhyolitic volcanites that belong to the Choiyoi Group. A new unsuspected, smaller debris flow happened $2 \mathrm{~h}$ later in the same alluvial track ( $\left.\mathrm{PC}_{2}\right)$. Deposit thickness reached $3.8 \mathrm{~m}$ and maximum blocks of $0.7 \mathrm{~m}$ in diameter were observed, 



Fig. 8 Debris flows in Picheuta area: a Google image on 15/02/2009 showing gullies of main debris flows in Picheuta area. b Deposit of PC2 debris flow over the previous PC1 that occurred $2 \mathrm{~h}$ earlier, both associated with the Picheuta $\mathrm{C}$ active alluvial cone system (Km 1,175.7). $\mathrm{c}$ Deposit of PC2 channelized into the previous one in the distal part of the alluvial fan. Predominance of red color is due to lithology

with the mean clasts size varying from 0.2 to $0.8 \mathrm{~m}$. In this case, the matrix was finer and more abundant, about 50 to $60 \%$ (Fig. 9).

During the same day, another large debris flow was reported $2 \mathrm{~km}$ down the valley (PA1, Fig. 8 and Table 2 ) on an active alluvial cone system identified in this paper as Picheuta A (Fig. 10). The channelized debris flow cut the alluvial cone in two tracks and blocked two sections of the road R7. The estimated volume for this event was $43,000 \mathrm{~m}^{3}$. Levees $5 \mathrm{~m}$ high are preserved in the main track (Fig. 10). Deposits along the two tracks show boulders 


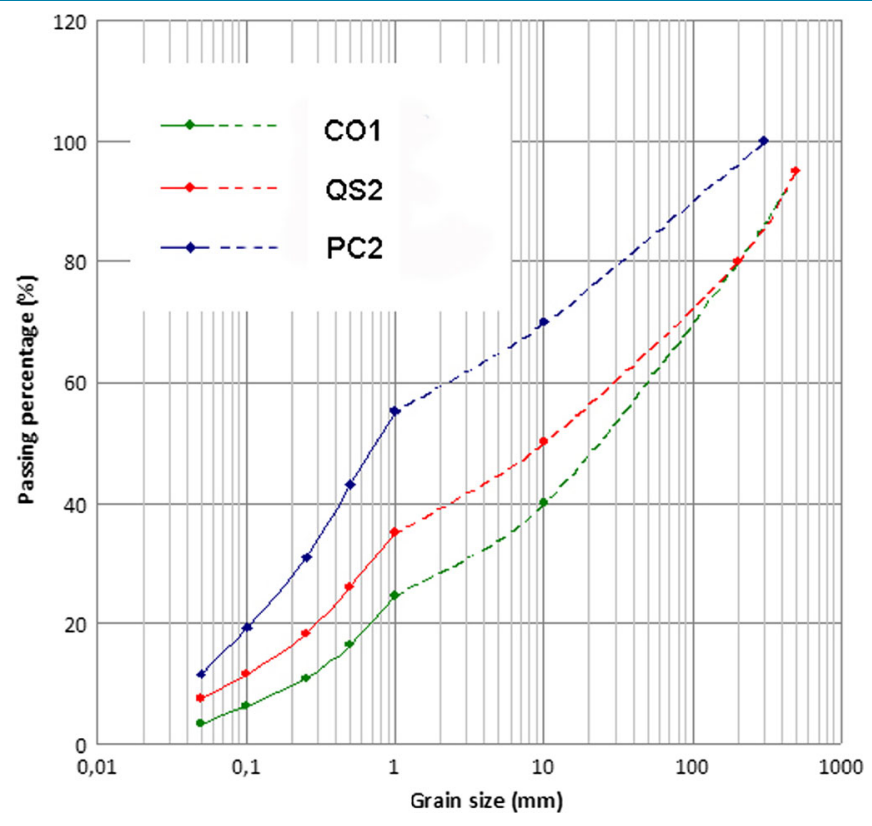

Fig. 9 Grain size distribution of Picheuta (PC2), Cortaderas (C01), and Quebrada Seca (QS2) debris flows. Dashed lines indicate field estimates, and full lines laboratory analyses of the finer matrix materials

varying from 0.2 to $3 \mathrm{~m}$ in diameter (Fig. 10). Some blocks reached 10 and $16 \mathrm{~m}^{3}$ in volume. The matrix content constitutes around $35 \%$ in the middle track deposits, reaching $55 \%$ at the toe. Boulder composition was mainly monolithic comprising rhyolitic volcanites of the Choiyoi Group. This debris flow ran $1.5 \mathrm{~km}$ from the source area descending $700 \mathrm{~m}$ over steep slopes ranging from $35^{\circ}$ to $65^{\circ}$. Deposit thickness was measured at $2 \mathrm{~m}$ on the road.

Another debris flow was reported in this sector of Picheuta area (PA2) with an estimated volume of $14,300 \mathrm{~m}^{3}$. This channelized event ran nearly $1 \mathrm{~km}$ until reaching the Mendoza River and blocked the road for about $100 \mathrm{~m}$ with a 1-m-thick deposit (Fig. 11). Splash marks on a volcanite outcrop show that the flow reached a height of $0.7 \mathrm{~m}$ near Mendoza River valley (Fig. 11b). However, levees in the middle track are thicker, reaching up to $1.8 \mathrm{~m}$. In this deposit, blocks of 0.3 to $0.7 \mathrm{~m}$ in diameter appear in an abundant fine red matrix (Fig. 11c). The area is well known for its past landslide activity, with previous debris flows in 1963, 1975, 1998, and 2006 (Moreiras 2005). However, estimated volumes of these ancient events, which rarely surpassed $6,000 \mathrm{~m}^{3}$, were a third part of the 2013 event (Moreiras 2006). Nevertheless, the availability of much material in this little basin could potentially generate a volume double that of the recent event.

Related to another alluvial cone in the same area, two further debris flows identified in this paper as $\mathrm{PB}_{1}$ and $\mathrm{PB}_{2}$ interrupted the road. The former deposited material along $20 \mathrm{~m}$ of the road with a thickness of $2.5 \mathrm{~m}$ and blocks up to $4 \mathrm{~m}$ in diameter, while $\mathrm{PB} 2$ was a smaller event covering $50 \mathrm{~m}$ along the road.

A large hyper-concentrated flow coming from the Quebrada Seca gully also interrupted the road on February 7 (QS1, Fig. 3 and Table 2). This flow reached the road depositing material of $3 \mathrm{~m}$ high and affecting $500 \mathrm{~m}$ of the road and entered the Mendoza River burying two bulldozers and other road machinery (Fig. 12). Thirty vehicles were stranded in the mountains as a result of this event. Debris material transported boulders up to 3 or $4 \mathrm{~m}^{3}$, and abundant matrix reaching $50 \%$ was observed (Fig. 12d). The grain size distribution of this soil matrix reveals mainly gravel (Fig. 9). A volume of $15,000 \mathrm{~m}^{3}$ was estimated for this event.

Toward the north, another channelized flow from Quebrada Seca affected the road in a section of $50 \mathrm{~m}$ after a culvert was clogged by the detrital material. At least $0.5 \mathrm{~m}$ of material was deposited on the road (Fig. 12e). A minor debris flow was reported in the northern channel of the Quebrada Seca fan, drained by a culvert that passes under R7 (Fig. 12f).

A further debris flow was reported between Quebrada del Camino and Quebrada Seca, with no drastic consequence. However, it must be noted that this active alluvial fan is fed by an extremely huge source area, covering an area of $60.10 \mathrm{~km}^{2}$. Perhaps this is the reason why numerous historical events in this gully have been documented, e.g., those in 1974, 1976, 1980, 1983, 1999, 2000, 2006, and 2007 (Moreiras 2005, 2006). The event recorded in 2007 had an estimated volume of $33,500 \mathrm{~m}^{3}$.

Furthermore, other 22 events were recorded on February 7 in Cortaderas area located $5 \mathrm{~km}$ upstream, along the international road. These events consisted mainly of rockfalls, but also debris flows, mobilizing a total volume estimated at 50,000 $\mathrm{m}^{3}$. Particularly, a rockfall in tunnel 13 buried four cars under mud and boulders (Fig. 13). This 1-m-high saturated deposit had a limited volume of up to $50 \mathrm{~m}^{3}$; however, it posed great danger. Fourteen persons including four children were isolated over the night before they were rescued by the police. The flows can be classified as debris flows (Table 2) as they are mainly composed of gravel and boulders with scarce $(<30 \%)$ sand and fines (Fig. 9). This event left a deposit of $1.5 \mathrm{~m}$ thick covering a 20 -m-long section of the road.

Rockfalls in the Mendoza Valley are associated with intensely fractured outcroppings of volcanic rocks or weathered granites that become water-saturated after sudden and local rainstorms during summer time. A low threshold precipitation (6-12 $\mathrm{mm}$ 


\section{Recent Landslides}


Fig. 10 Debris flows that occurred on 7 February in Picheuta area generated on alluvial fan A (Km 1173.1): a location of two tracks of PA1. b Debris flow deposit removed from the international road $\mathrm{N}^{\circ}$. $\mathrm{c}$ Characteristics of channelized debris deposit where matrix content and boulder sizes could be observed. $\mathbf{d}$, e Greatest boulders observed in the PB1 debris flow

per day) was previously determined for this region (Moreiras 2006), but some historic debris flows channelized into the Quebrada Seca gully occurred with $23 \mathrm{~mm}$ of precipitation, as recorded at Uspallata station. However, as noted initially by Moreiras (2006), threshold value estimation is based on scarce meteorological stations along the Mendoza River valley, excluding upper catchment areas where most of the debris flows are generated by mobilization of debris and boulders. These hyperconcentrated flows when channelized into long and steep gullies may reach velocities of up to 35 to $50 \mathrm{~m} / \mathrm{s}$ (Moreiras 2009).
Several rockfalls were reported in an unstable talus zone also located in the Picheuta area. Another debris flow was reported in the Arroyo Negro gully. Later, on 9 February, another flow affected the Route 149 in Uspallata after a rainstorm and a minor event occurred in the Quebrada Seca at midday on the 13th.

In Chile, in the evening of 8 February 2013, intense localized rainfall produced at least nine debris flows in small tributaries of the Colorado River ( $33.5^{\circ}$ S, Fig. 2 and Table 2), a main branch of the Maipo basin along the route to the Maitenes and Alfalfal power stations. Other minor mudflows were located at the Lagunillas ski 


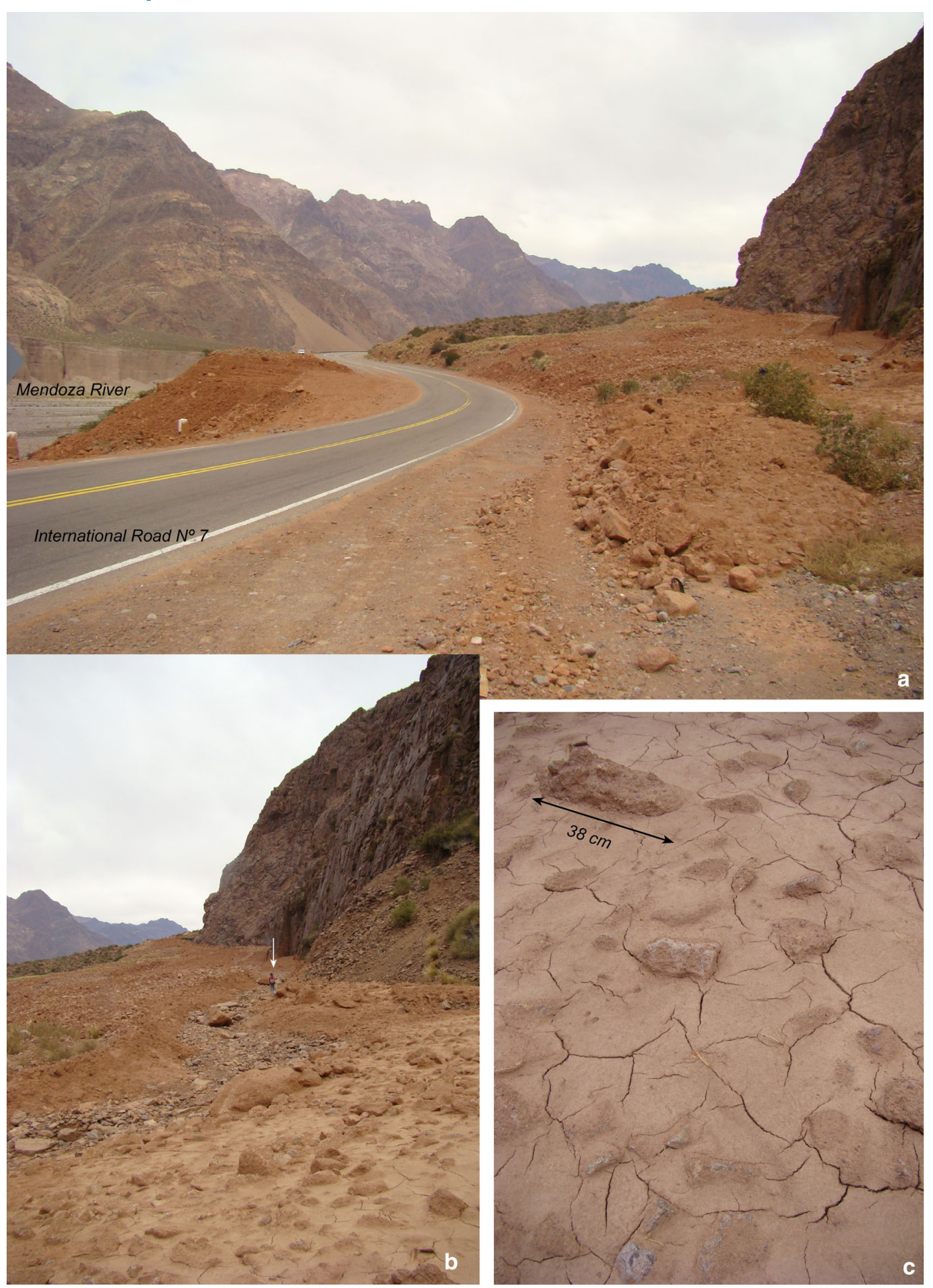

Fig. 11 Pictures of PA2 in the Picheuta area $(\mathrm{Km} \mathrm{1,171).} \mathrm{a} \mathrm{Debris} \mathrm{flow} \mathrm{deposit} \mathrm{removed} \mathrm{from} \mathrm{international} \mathrm{road.} \mathbf{b}$ Splash marks near Mendoza River valley showing the thickness of the deposit; the arrow indicates a person as scale. $\mathrm{c}$ Detail of debris flow matrix

center east of San José de Maipo Town (Fig. 2). On the same day, some flows affected tributaries of the Aconcagua River, including a particularly large debris flow in the Riecillos Creek (32.8 ${ }^{\circ}$ S. Fig. 2).

The rain in the Colorado Valley generated concentrated surface water flow in nine small and narrow gullies of $\sim 1 \mathrm{~km}$ long in a section of about $10 \mathrm{~km}$ along the valley (Fig. 14), blocking the road that runs a few hundred meters parallel to the river (Sernageomin 2013a). The gully catchments reach maximum elevations between 1500 and $2500 \mathrm{~m}$ asl, and thalweg slopes vary from between $20^{\circ}$ and $25^{\circ}$ in the gullies to $5^{\circ}-10^{\circ}$ in the depositional area. The thickness of the deposits varies between 1 and $2 \mathrm{~m}$ in the deposition area, diminishing to $20-30 \mathrm{~cm}$ up in the gullies. Splash marks 


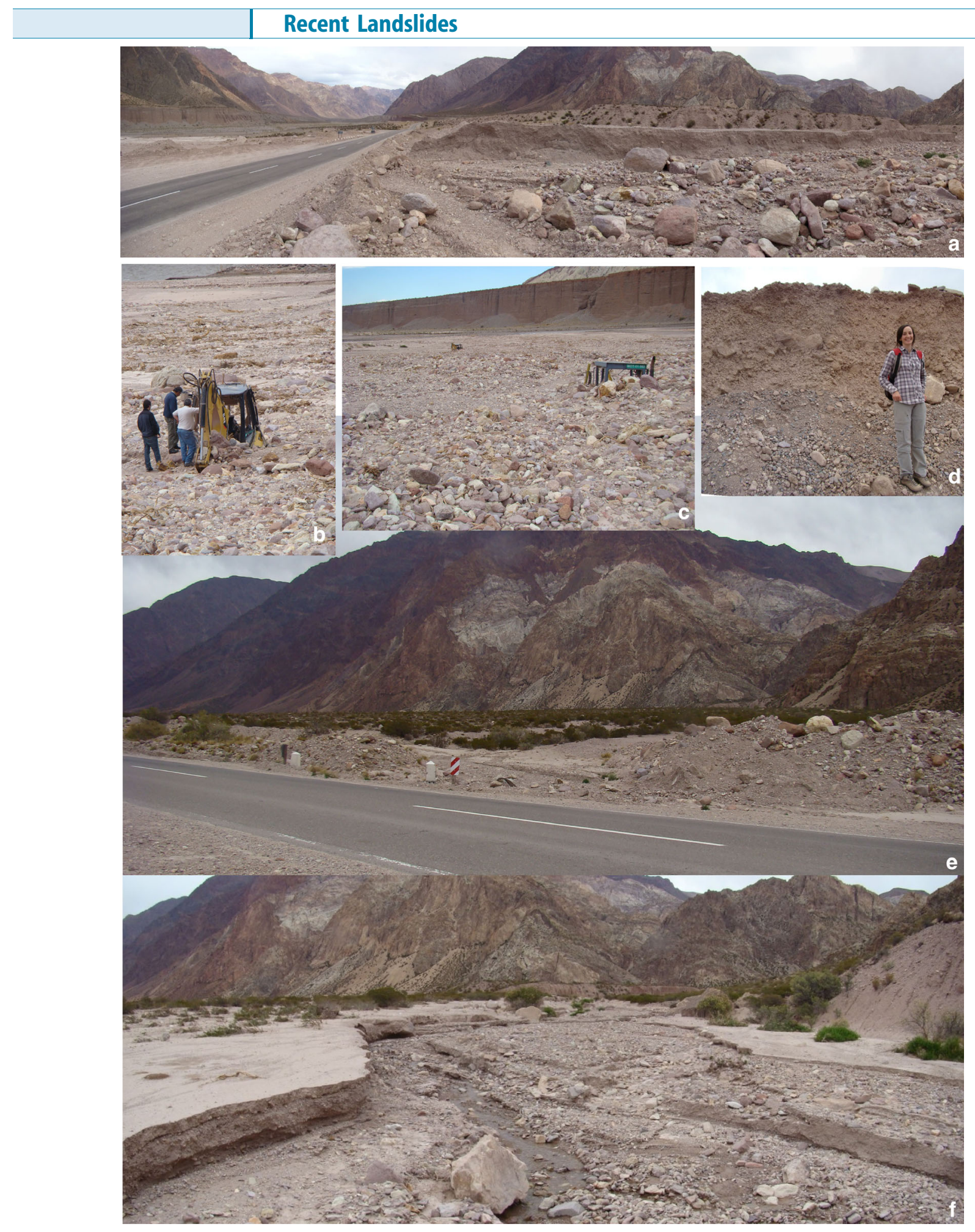

Fig. 12 Pictures of the channelized debris flows in different parts of the Quebrada Seca alluvial cone system: a hyper-concentrated flow QS1 (Km 1,171) that severely impacted on international road. $\mathbf{b}$ Detail of bulldozer buried by the QS1 its path into the Mendoza River. $\mathbf{c}$ Both bulldozers buried by the flow. $\mathbf{d}$ Debris material with abundant matrix content $(50 \%)$. e Debris flow channelized into another channel invading the road due to culvert obstruction. $\mathbf{f}$ Minor debris flow coming from the northernmost channel

vary between 2 and $5 \mathrm{~m}$ high along the gullies and less than $2 \mathrm{~m}$ next to the road (Fig. 14). Profiles in the deposits show that this type of alluvial activity is recurrent, with fresh deposits on top of older but very similar deposits (Fig. 14). Field and laboratory granulometric analyses show that the deposits vary from poorly to well graded, being composed of decimetric blocks in a matrix of mud, sand, and gravel with about $10 \%$ of fine-grained sediments, classifying as debris flows (Fig. 15 and Table 2).

On the same day, a larger debris flow (estimated volume exceeding $10,000 \mathrm{~m}^{3}$ ) affected the Riecillos Creek, a 20-km-long 


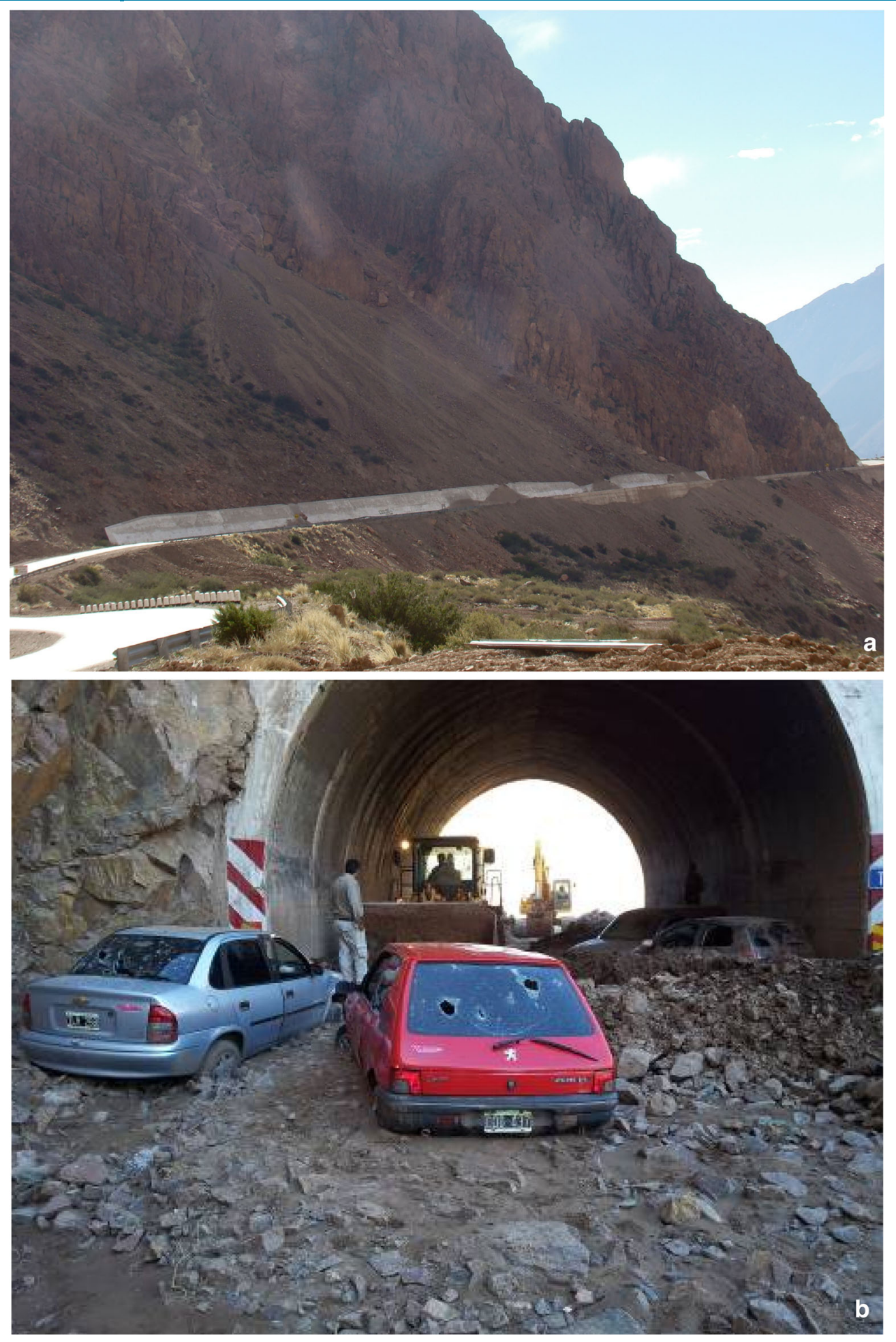

Fig. 13 Pictures of rockfalls and debris flows reported in the Cortaderas area: a rockfall generated from talus cones passing over a contention wall along $1.5 \mathrm{~km}$ of international road, and $\mathbf{b}$ rockfall in tunnel 13 burying four cars $(\mathrm{Km} \mathrm{1,178)}$

north-south trending valley, and a secondary gully in the Aconcagua Valley, which damaged several houses and two minor bridges in the village of Riecillos located in the alluvial fan area (Moreiras and Sepúlveda. 2013). The Riecillos Creek catchment reaches up to $3600 \mathrm{~m}$ asl, with a gentle thalweg slope of about $5^{\circ}$. At its confluence with the Aconcagua River, the creek forms a large alluvial fan with an average slope of $2^{\circ}-3^{\circ}$, where the Riecillos Village is situated (Fig. 16). The main flow left in the village area splash marks of up to 3-4 $\mathrm{m}$ high in trees and on houses. Close to the fan apex, the flow did not leave major deposits in the blocky creek bed, with the exception of 30-40-cm thick overflow deposits. In the middle section of the debris fan, stratified debris flow 


\section{Recent Landslides}
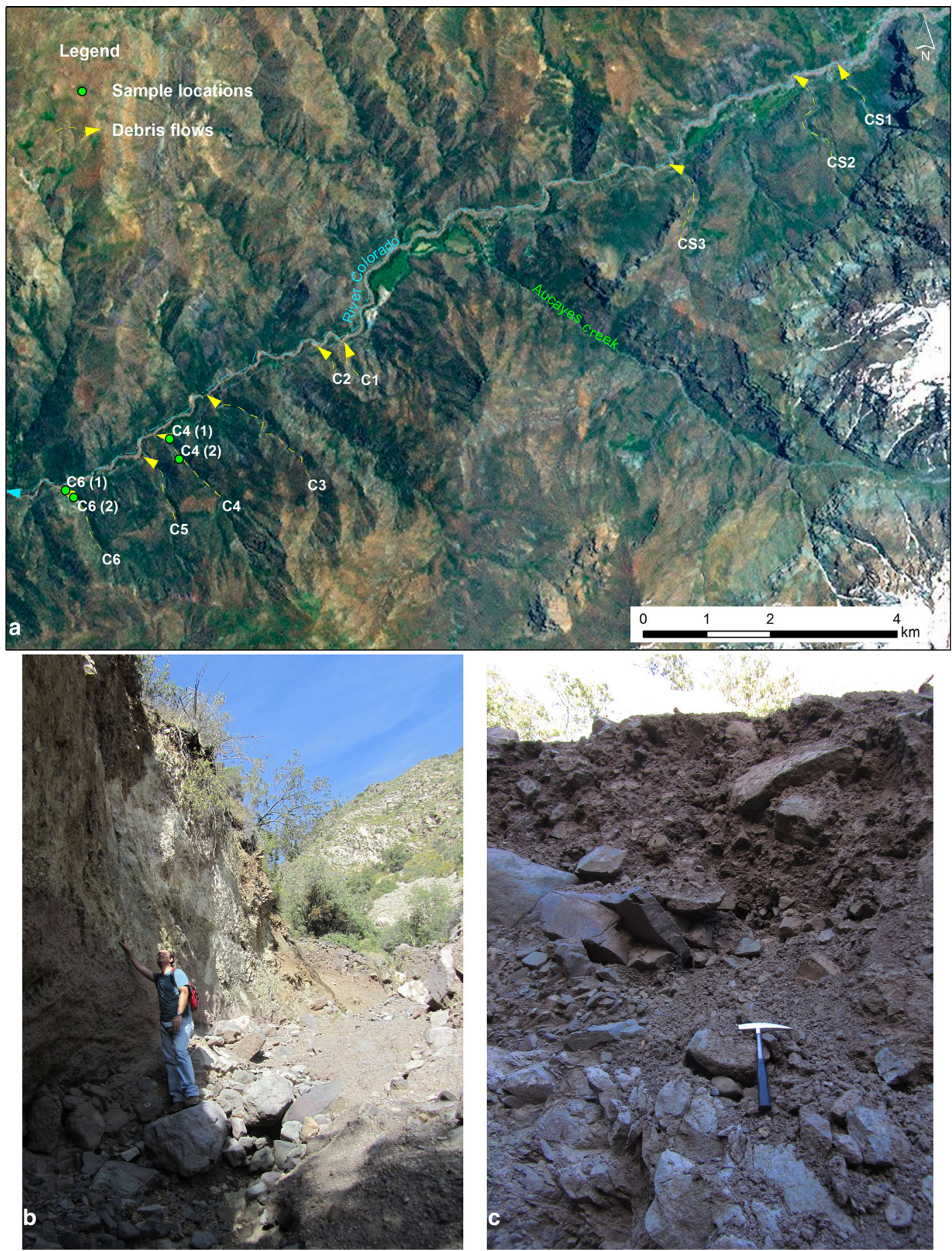

Fig. 14 a Location of debris flows in lateral gullies of the Colorado valley; $\mathbf{b}$ example of splash marks; $\mathbf{d}$ example of 2013 fresh deposit above older, similar debris flow deposits

deposits, including fresh sediments, can be observed, with rock blocks generally less than $20 \mathrm{~cm}$ in a sandy matrix. The main deposits are located in the distal part of the alluvial fan, showing blocks exceeding $50 \mathrm{~cm}$ but mainly below $30 \mathrm{~cm}$ in a sandygravelly matrix. Fine-grained material is less abundant than in the apex area, possibly due to washing by the creek flow (Fig. 15). The flows reached the Aconcagua River, leaving mud deposits across the international road on the opposite side of the main valley.

\section{Discussion}

The debris flow events during the 2013 Southern Hemisphere summer show that several events may be simultaneously produced by very localized, heavy rainfall. The extent of the storms producing the flows may be just a few kilometers, so that they may not have been properly measured by meteorological stations, as shown in the Maipo Valley in Chile, where the records are quite variable (Table 1). While the monthly values at some stations are comparable to the average rainfall reported in the literature (Garreaud 

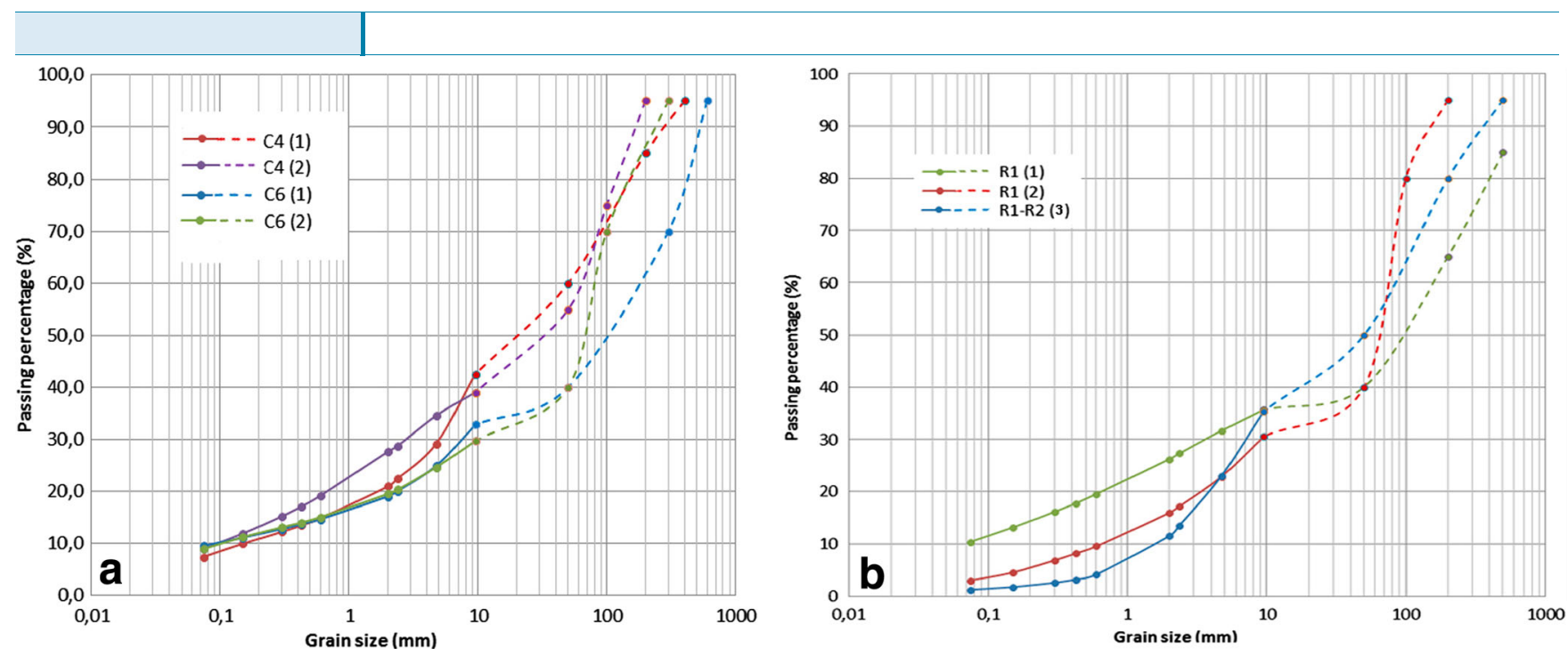

Fig. 15 Grain size distribution of 8 February 2013 debris flow deposits at a lateral tributary gullies C4 and C6 in Colorado Valley and b Riecillos Creek alluvial fan. Sample locations in Figs. 13 and 15

and Rutllant 1997), the daily peaks during the events are generally small or negligible, suggesting that the triggering storms are very local, at least in Chile. This fact along with the lack of stations in the catchments where the flows are generated makes it difficult to determine the rainfall threshold values for the triggering of these events in both countries. Nevertheless, it was a wet summer season with rainfall in the region well above average . For instance, the precipitation recorded in Mendoza City until mid-February (6o $\mathrm{mm}$ ) was $50 \%$ higher than the mean monthly historical precipitation. New but fewer cases were again detected in the summer of 2014, including new flows in Riecillos and Quebrada Seca. This raises the question of the potential effects of climate change. Presumably, these heavy rainfall events in the region will be more frequent (IPCC 2009) and therefore the hazard related to debris flows in the mountains of central Chile and Argentina would also be increased. Even though general circulation model simulations predict a significant decrease in precipitation over the region for the next five decades (Cubasch 2001), and a strong interdecade variability with an overall negative trend (Quintana 2004) is shown by annual and winter rainfall variations in central
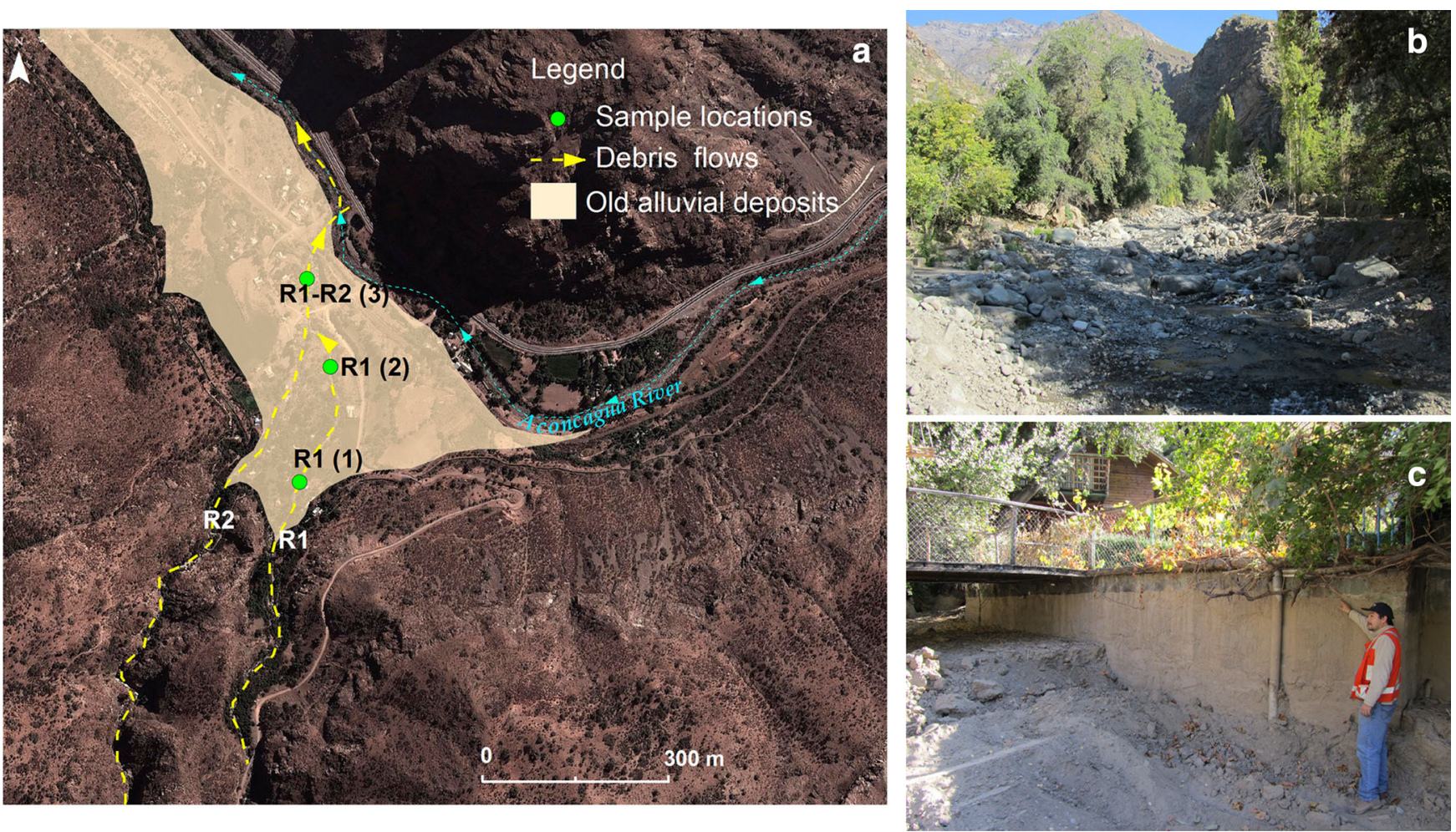

Fig. 16 a Location of debris flows in Riecillos Creek and secondary gully; b debris flow deposits in the apex area; c splash marks in Riecillos Creek 
Chile between $30^{\circ}$ and $33^{\circ} \mathrm{S}$, increased rainfall anomalies took place within this period. Landslide-inducing precipitation in summer seems to be conditioned by the Atlantic Anticyclone. The cluster of events of January and February 2013 were first recorded in the Argentinean Andes and 1 day later in Chile, suggesting that precipitation may be related to the eastern Anticyclone.

Most flow deposits show a fine-grained soil matrix usually ranging between 10 and $20 \%$, classifying as debris flows according to Hungr et al. (2014; Table 2). The relatively high content of fines favors the movement as viscous flows. The sand and gravel content is variable, with a tendency to be slightly coarser in Chile, where the source basins tend to be smaller and steeper, producing flows of smaller volume and coarser materials compared with those of Mendoza Valley in Argentina.

Debris flows channelized into alluvial cones have been widely reported; therefore, they are commonly considered during the building of road infrastructure. However, the volume and frequency of these events have often been misjudged. Basic prevention measures were omitted in many sections of the $\mathrm{R}_{7}$ international road in the Mendoza Valley. This is the case of debris flows G2, G3, $\mathrm{G}_{4}$, and $\mathrm{G}_{5}$ reported on January 14. Moreover, major damage caused by many debris flows that occurred in the Picheuta area in February was probably due to no or inadequate provision of mitigation measures, e.g., division channels and debris retention structures. Only the Quebrada Seca gully has been provided with draining culverts, but the dimensions seem to be inadequate as they were blocked during the summer 2013 events. Similarly, in the case for the San Alfonso and Riecillos Creeks in Chile, there were undersized bridges crossing the streams, while other cases reported here lacked mitigation measures for debris flows or flash floods.

Not only debris flow processes have been underestimated. Likewise, talus areas have been regarded as rockfall-prone areas but ignoring the susceptibility of fine material to generate gravelly and sandy debris avalanches. Some retention walls have been built at the toe of this talus, but they are ineffective protection measures for the road as boulders or flows commonly overtop those structures.

This extreme and dramatic situation had a significant economic cost for the province of Mendoza in Argentina and the Santiago and Valparaiso regions in Chile. In Mendoza, six helicopters were required to rescue people and transport food, water, medicines, and clothing to affected tourists. Specific earth-moving equipment had to be deployed for almost 20 days following the event for clearance of mud and rocks from the road surface. At least 30 bulldozers and front loaders were used and 3 were buried by moving debris at the Quebrada Seca gully. The total economic loss due to disruption to international road traffic was over 3 million dollars as. In Chile, millions lacked a basic water supply for hours and in some cases several days. The events took the authorities and communities by surprise. If predictions of increasing heavy rainfall events due to global warming are correct, the risk faced by the local communities will also increase. The region has a record of historic debris flows, some of them much larger than those reported here (Hauser 2000; Moreiras 2009); thus, the events of 2013 must be taken as a warning. The evidence points to the need for taking into account these natural hazards affecting our vulnerable societies in the planning and design of infrastructure. Mountain road infrastructure must be much more robust and provided with structural mitigation measures, and water supply companies must not entirely rely on surface running water from main rivers as they may quickly be overloaded with sediment when debris flows occur in the highlands. For a proper design of future mitigation measures, a well-documented description of the debris flow events and their main characteristics would be useful, along with further investigations into the meteorological conditions that trigger these landslides.

\section{Concluding remarks}

The January and February 2013 rainfall-induced landslides in the Chilean and Argentinean central Andes were triggered by local summer storms. They can be classified based on their composition, grain size, and movement characteristics as debris flows, debris avalanches, and rockfalls. Most of the landslides correspond to debris flows, which caused serious disruption to the road infrastructure and had a large socio-economic impact on major cities such as Santiago, Mendoza, and Valparaiso, due to the potable water supply relying on running river water, which was overloaded with sediments from the debris flows in lateral gullies. The very localized nature of the triggering storms and lack of a dense network of meteorological stations preclude an analysis based on good quality rainfall data. The summer rainfall patterns in the region need to be investigated further in order to produce rainfall threshold models applicable to hazard analyses. Most flows were formed from remobilization of loose debris in short but steep gullies forming tributaries of the main valleys. The deposits are mostly coarse grained with a silt and clay content usually over $10 \%$, which favors the channelized movement of viscous flows in the lateral gullies. These events showed a high vulnerability of the road and water supply systems, which can be severely affected by the occurrence of relatively moderate debris flow events. Several lessons can be learned for the development of engineering works to mitigate the effects of these landslide hazards, which are expected to be repeated maybe more frequently in the near future due to the effect of climate change.

\section{Acknowledgments}

The authors acknowledge the collaboration of Hugo Ochoa, Sofía Rebolledo, Mauricio Reyes, Ailin Railao, and Carolina Lauro during field work and laboratory analyses. We thank the AES-GENER hydropower company for sharing their meteorological records. We are especially grateful to with Walter Pérez from the DNV (Argentina) who let us use his report of events of 2013 summer and head of this department Eng. Rivas. Many thanks also to René Garreaud and Maximiliano Viale for their discussions on climatic issues and to Jacobus Le Roux for his valuable comments and proofreading of the draft manuscript. This work was financed by the Faculty of Physical and Mathematical Sciences, University of Chile (S. Sepúlveda) and project PIP 628 (S.M. Moreiras).

\section{References}

Araneo DC, Compagnucci RH (2008) Atmospheric circulation features associated to Argentinean Andean rivers discharge variability. Geophys Res Lett 35(1), L01805

Cubasch U (2001) Projections of future climate change. In: J. T. Houghton et al. (eds), Climate Change 2001: The Scientific Basis, Cambridge University Press, pp 525-582

DGA (2013) Sistema Nacional de Información del Agua (SNIA). Dirección General de Aguas. Ministerio de Obras Públicas. Chile. www.snia.dga.cl

DMC (2001) Climatología Regional. Dirección Meteorológica de Chile p 47

DNV (2013) Informe aludes R.N. No 7 y R.N. N 149. Dirección Nacional de Vialidad. unpublished report 
Falvey M, Garreaud R (2007) Wintertime precipitation episodes in central Chile: associated meteorological conditions and orographic influences. J Hydrometeorol 8:171-193

Fock A (2005) Cronología y tectónica de la exhumación en el Neógeno de los Andes en Chile central entre los $33^{\circ}$ y $34^{\circ} \mathrm{S}$. MSc Thesis, Universidad de Chile, Departamento de Geología: $\mathrm{p} 179$

Garreaud R, Rutllant J (1996) Análisis meteorológico de los aluviones de Antofagasta y Santiago de Chile en el período 1991-1993. Atmosfera 9:251-271

Garreaud R, Rutllant J (1997) Precipitación estival en los Andes de Chile central: aspectos climatológicos. Atmosfera 10:191-211

Hauser A (2000) Remociones en masa en Chile. Servicio Nacional de Geología y Mlnería, Boletín No.59

Hungr 0, Leroueil S, Picarelli $L$ (2014) The Varnes classification of landslide types, an update. Landslides 11:167-194

IPCC (2009) IPCC Expert Meeting on Detection and Attribution Related to Anthropogenic Climate Change. In: Stocker T, Field C, Dahe Q, Barros V, Plattner G, Tignor M, Midgley $P$, Ebi K. (eds). The World Meteorological Organization Geneva, Switzerland

Moreiras SM (2005) Climatic effect of ENSO associated with landslide occurrence in the Central Andes, Mendoza province, Argentina. Landslides 2(1):53-59

Moreiras SM (2006) Frequency of debris flows and Rockfall along the Mendoza river valley (central Andes), Argentina. Special issue Holocene environmental catastrophes in South America. Quat Int 158:110-121

Moreiras SM (2009). Main hazardous zone along the Mendoza river valley. Internal report to National Vial Department (DNV). Dirección Nacional de Vialidad. p 45

Moreiras SM, Sepúlveda SA (2013) The high social and economic impact 2013 summer debris flow events in Central Chile and Argentina. Boll Geofis Teor Appl 54(2):181184

Moreiras SM, Lisboa S, Mastrantonio L (2012) The role of snow melting upon landslides in the central Argentinean Andes. Earth Surf Process Landf. doi:10.1002/esp.3239

Naranjo JA, Varela J (1996) Flujos de detritus y barro que afectaron el sector oriente de Santiago el 3 de mayo de 1993. Servicio Nacional de Geología y Mlnería, Boletín No.47

Quintana JM (2004) Factors affecting Central Chile rainfall variations at interdecadal scales (in Spanish). M.S. Thesis, Departamento de Geofísica, Universidad de Chile, p 88

Ramos VA (1996) Evolución tectónica de la alta cordillera de San Juan y Mendoza. In: Geología de la región del Aconcagua, provincias de San Juan y Mendoza. Ramos V (ed). Subsecretaria de Minería de la Nación. Dirección Nacional del Servicio Geológico Anales 24(1): 447-460

Sepúlveda SA, Padilla C (2008) Rain-induced debris and mud flow triggering factors assessment in the Santiago Cordilleran foothills, Central Chile. Nat Hazards 47:201-215
Sepúlveda SA, Rebolledo S, Vargas G (2006) Recent catastrophic debris flows in Chile: geological hazard. climatic relationships and human response. Quat Int 158:83-95

Sepúlveda SA, Astroza M, Kausel E, Campos J, Casas E, Rebolledo S, Verdugo R (2008) New findings on the 1958 Las melosas earthquake sequence, central Chile: implications for seismic hazard related to shallow crustal earthquakes in subduction zones. J Earthq Eng 12(3):432-455

SERNAGEOMIN (2013a) Reconocimiento de depósitos de flujos de detritos en cursos fluviales de la cuenca del río Maipo, resultantes de remociones en masa del 21 de enero y 8 de febrero de 2013 en la Región Metropolitana, y priorización para su eventual limpieza, a objeto de prevenir su impacto en el normal abastecimiento de agua potable para la Región Metropolitana. Servicio Nacional de Geología y Minería. unpublished report

SERNAGEOMIN (2013b) Informe preliminar: Remociones en masa ocurridas el 21 de enero de 2013 entre Coya y la Bocatoma Pangal. Región del Libertador Bernardo O'Higgins. Servicio Nacional de Geología y Minería. unpublished report

Thiele R (1980) Hoja Santiago. Instituto de Investigaciones Geológicas, Carta Geológica de Chile No39

Viale M, Garreaud R (2014) Summer precipitation events over the western slopes of the subtropical Andes. Mon Weather Rev 142:1074-1092

Viale M, Nuñez MN (2011) Climatology of winter orographic precipitation over the subtropical central Andes and associated synoptic and regional characteristics. J Hydrometeorol 12(4):481-507

Wall R, Sellés D, Gana P (1999) Area Tiltil-Santiago (1:100,000 scale map), Región Metropolitana. Servicio Nacional de Geología y Minería, Mapas Geológicos vol. 11

S. A. Sepúlveda $(\varangle) \cdot$ M. Lara · A. Alfaro

Departamento de Geología,

Universidad de Chile,

Plaza Ercilla 803, Santiago, Chile

e-mail: sesepulv@ing.uchile.cl

S. M. Moreiras

CONICET-IANIGLA (CCT)

Av. Dr. Ruiz Leal s/n. Parque Gral, San Martín, Mendoza, Argentina

A. Alfaro

Servicio Nacional de Geología y Minería,

Av. Santa María 0104, Providencia, Santiago, Chile 